\title{
Growth of $\mathrm{BiVO}_{4}$ Nanoparticles on a $\mathrm{Bi}_{2} \mathrm{O}_{3}$ Surface: Effect of Heterojunction Formation on Visible Irradiation-Driven Catalytic Performance
}

\author{
Osmando F. Lopes, ${ }^{* \dagger, \ddagger, \| \odot ~ K e l e ~ T . ~ G . ~ C a r v a l h o, ~}{ }^{\ddagger}$ Waldir Avansi, Jr., ${ }^{\S}$ and Caue Ribeiro ${ }^{\ddagger}$ \\ ${ }^{\dagger}$ Departamento de Química, Universidade Federal de São Carlos - UFSCar, Rod. Washington Luiz, km 235, CEP 13565-905, São \\ Carlos-SP, Brazil \\ \$Laboratório Nacional de Nanotecnologia para o Agronegócio (LNNA) - Embrapa Instrumentação, Rua XV de Novembro, 1452, \\ CEP 13560-970, São Carlos-SP, Brazil \\ ${ }^{\S}$ Departamento de Física, Universidade Federal de São Carlos, Rod. Washington Luiz, km 235, CEP 13565-905, São Carlos-SP, Brazil
}

\section{Supporting Information}

\begin{abstract}
Heterostructured materials composed of different semiconductors can be used to decrease rapid charge carrier recombination in photocatalysts, but the development of efficient synthesis methods for these materials remains a challenge. This work describes a novel strategy for tailoring heterostructures that is based on the solubility difference between two semiconductors with at least one metal in common. The growth of $\mathrm{BiVO}_{4}$ on a preformed $\mathrm{Bi}_{2} \mathrm{O}_{3}$ particle

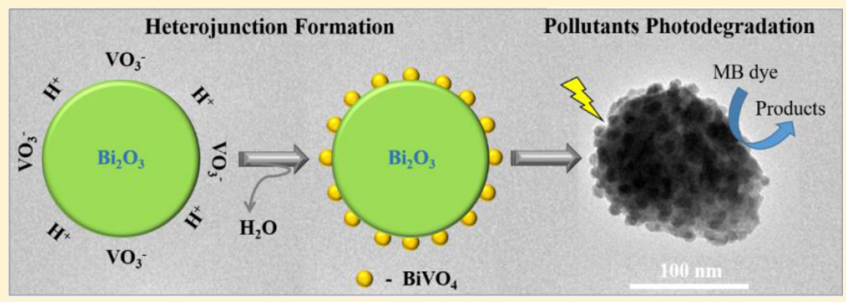
was used as a model for heterojunction formation. The number of $\mathrm{Bi}_{2} \mathrm{O}_{3} / \mathrm{BiVO}_{4}$ heterojunctions was tuned using synthesis variables (temperature and $\mathrm{V}$ concentration) and the particle size of the preformed $\mathrm{Bi}_{2} \mathrm{O}_{3}$. The synthesis of the $\mathrm{Bi}_{2} \mathrm{O}_{3} / \mathrm{BiVO}_{4}$ heterostructures using $\mathrm{Bi}_{2} \mathrm{O}_{3}$ nanoparticles resulted in a larger quantity of heterojunctions due to the higher solubility of the nanoparticles compared to micrometric $\mathrm{Bi}_{2} \mathrm{O}_{3}$, which led to a classical heterogeneous precipitation on the preformed surfaces. The proposed growth mechanism was effective for obtaining heterostructured $\mathrm{Bi}_{2} \mathrm{O}_{3} / \mathrm{BiVO}_{4}$ semiconductors with enhanced photocatalytic performances compared to the isolated phases. The greater photoactivity of the heterostructures could be explained by the increased spatial separation in the photogenerated electron/hole pairs due to the formation of a type-II heterostructure and was observed by time-resolved photoluminescence analysis. In this case, the photogenerated electrons were transferred from the conduction band of the p-type semiconductor $\left(\mathrm{Bi}_{2} \mathrm{O}_{3}\right)$ to the n-type $\left(\mathrm{BiVO}_{4}\right)$ semiconductor, while the photogenerated holes were transferred from the valence band of the ntype semiconductor to the p-type semiconductor.
\end{abstract}

\section{INTRODUCTION}

The formation of heterostructures between semiconductors has been widely studied for applications in heterogeneous photocatalysis, such as organic pollutant degradation, ${ }^{1-6}$ water splitting, ${ }^{7-9}$ and artificial photosynthesis. ${ }^{10-13}$ This topic is of great interest in physical chemistry because it involves the potential to solve several problems related to water treatment and renewable energy, and the complete understanding of the charge transfer mechanism in heterostructures is required. A special feature of a suitable heterostructure is its capacity to increase the lifetime of a photogenerated electron/hole pair by suppressing its recombination. ${ }^{14-16}$ As a result, the charges instead migrate to the semiconductor surface and increase the occurrence of redox reactions on the heterostructure surface. ${ }^{17-24}$ In addition, the system formed between the $\mathrm{BiVO}_{4}$ (type $\mathrm{n})^{25,26}$ and $\mathrm{Bi}_{2} \mathrm{O}_{3}$ (type $\mathrm{p}$ ) semiconductors ${ }^{27,28}$ exhibits promising electronic properties for the creation of type-II heterostructures (with $\mathrm{p}-\mathrm{n}$ junctions). ${ }^{29,30}$ Due to its band gap characteristics, this heterostructure can be activated by visible radiation, which is an important feature for photocatalytic applications under natural sunlight. ${ }^{25,26,31}$

Heterostructured $\mathrm{Bi}_{2} \mathrm{O}_{3} / \mathrm{BiVO}_{4}$ has been studied due to its potential for use in the photocatalytic degradation of organic pollutants $^{32,33}$ and water splitting in photoelectrochemical (PEC) cells. ${ }^{34}$ However, the formation of efficient heterojunctions between these two semiconductors remains a challenge. ${ }^{35,36}$ Recently, $\mathrm{Ye}$ et al. ${ }^{34}$ proposed a synthesis method for building heterostructured $\mathrm{Bi}_{2} \mathrm{O}_{3} / \mathrm{BiVO}_{4}$ films with a remarkable photocurrent in PEC cells. However, this method is based on multiple steps and favors the formation of a spurious phase $\left(\mathrm{V}_{2} \mathrm{O}_{5}\right)$. Cheng et al. ${ }^{32}$ reported an interesting method for obtaining $\mathrm{BiVO}_{4} / \mathrm{Bi}_{2} \mathrm{O}_{3}$ composites using a mild, one-step hydrothermal process, but the ratio between $\mathrm{Bi}_{2} \mathrm{O}_{3}$ and $\mathrm{BiVO}_{4}$ could not be controlled. Other authors have used some additives/surfactants or a solvothermal method to obtain

Received: April 8, 2017

Revised: June 3, 2017

Published: June 5, 2017 
$\mathrm{BiVO}_{4} / \mathrm{Bi}_{2} \mathrm{O}_{3}$. However, the use of a surfactant or solvent can poison the surface of the semiconductor. ${ }^{33,37,38}$ Additionally, the ratio of $\mathrm{Bi}_{2} \mathrm{O}_{3}$ to $\mathrm{BiVO}_{4}$ and the morphology for either material was not controlled. ${ }^{32,33,37,38}$ In the work of $\mathrm{Li}$ and Yan, ${ }^{39} \mathrm{Bi}_{2} \mathrm{O}_{3} / \mathrm{BiVO}_{4}$ heterostructures were obtained using surfactants with a calcination step at $600{ }^{\circ} \mathrm{C}$, but the thermal treatment at high temperatures can negatively affect the properties of the nanocrystals due to surface dehydroxylation and surface area reduction. Therefore, the main challenge to overcome is the difficulty in controlling the simultaneous crystallization of two different components with suitable physical, chemical, and electronic properties through a surfactant-free and mild (low temperatures) synthesis method. $^{17,36}$

The use of a preformed particle to build heterostructures is of interest because the morphology and creation of interfaces can be easily controlled. ${ }^{17,36,40}$ Since $\mathrm{Bi}_{2} \mathrm{O}_{3}$ and $\mathrm{BiVO}_{4}$ have $\mathrm{Bi}$ in common, it is possible to create an interface between the semiconductors by growing one phase on the sacrificial surface of a preformed particle using the difference in the solubility of the compounds. Therefore, the aim of this study was to develop a novel and efficient synthesis method to obtain $\mathrm{Bi}_{2} \mathrm{O}_{3} / \mathrm{BiVO}_{4}$ heterostructures using a hydrothermal treatment and to evaluate the influence of the heterojunction on photocatalytic performance. The effects of the particle size (micrometric or nanometric) of the preformed $\mathrm{Bi}_{2} \mathrm{O}_{3}$, the hydrothermal treatment temperature, and the amount of $\mathrm{BiVO}_{4}$ grown on the $\mathrm{Bi}_{2} \mathrm{O}_{3}$ surface were investigated. The photoactivity of the heterostructures was probed using the photodegradation of methylene blue dye (MB) under visible irradiation. A mechanism was proposed for the effect of the charge transfer on the increased charge carrier lifetime of the type- $\mathrm{II}_{\mathrm{Bi}_{2}} \mathrm{O}_{3}$ / $\mathrm{BiVO}_{4}$ heterostructure that was formed.

\section{EXPERIMENTAL SECTION}

Synthesis of $\mathrm{Bi}_{2} \mathrm{O}_{3} / \mathrm{BiVO}_{4}$ Heterostructures. The synthesis of the heterostructured $\mathrm{Bi}_{2} \mathrm{O}_{3} / \mathrm{BiVO}_{4}$ samples was performed by dispersing $0.2 \mathrm{~g}$ of either micrometric (SigmaVetec, 98\%) or nanometric (Sigma-Aldrich, 90-210 nm particle size, $99.8 \%$ ) preformed $\mathrm{Bi}_{2} \mathrm{O}_{3}$ precursor in $30 \mathrm{~mL}$ of distilled water, followed by the addition of an $\mathrm{NH}_{4} \mathrm{VO}_{3}$ precursor (water solubility at $25{ }^{\circ} \mathrm{C}$ is $7.81 \mathrm{~g} \cdot \mathrm{L}^{-1}$ ) at different $\mathrm{Bi}: \mathrm{V}$ molar ratios $(1: 1$ or $1: 2)$. The resulting reaction mixture was hydrothermally treated at 150 or $200{ }^{\circ} \mathrm{C}$ for $12 \mathrm{~h}$. The materials obtained were washed with distilled water, centrifuged three times to remove impurities, and dried in an oven at 50 ${ }^{\circ} \mathrm{C}$. Figure 1 shows a proposed mechanism for the growth of the $\mathrm{BiVO}_{4}$ particles on the $\mathrm{Bi}_{2} \mathrm{O}_{3}$ sacrificial surface, which was driven by the solubility difference between the compounds. For

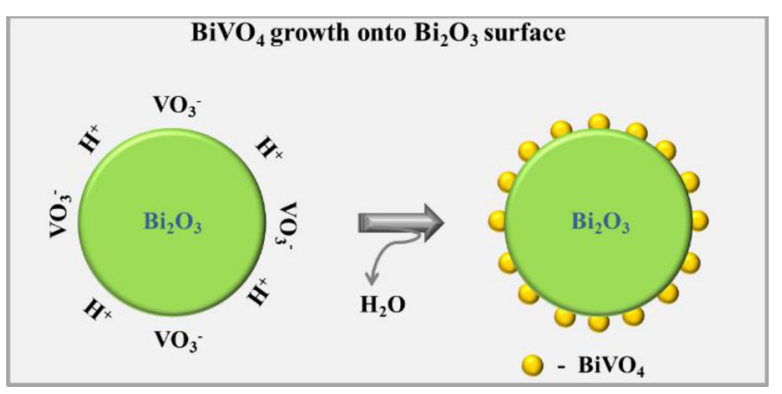

Figure 1. Proposed growth of $\mathrm{BiVO}_{4}$ on a $\mathrm{Bi}_{2} \mathrm{O}_{3}$ surface. comparative purposes, pure $\mathrm{BiVO}_{4}$ was synthesized using a similar method with $\mathrm{Bi}\left(\mathrm{NO}_{3}\right)_{3} \cdot 5 \mathrm{H}_{2} \mathrm{O}$ and $\mathrm{NH}_{4} \mathrm{VO}_{3}$ in $30 \mathrm{~mL}$ of distilled water at a $\mathrm{Bi}: \mathrm{V}$ molar ratio of $1: 1$, and this mixture was hydrothermally treated at $150{ }^{\circ} \mathrm{C}$ for $12 \mathrm{~h}$.

The heterostructured samples are referred to as $s$-Het- $x: y T$, where $s$ is the size scale of the Bi precursor ( $m$ for micrometric and $n$ for nanometric), $x: y$ is the $\mathrm{Bi}: \mathrm{V}$ molar ratio, and $T$ is the crystallization temperature.

Powder Characterization. X-ray diffraction (XRD) patterns were recorded using a Shimadzu XRD 6000 diffractometer with Ni-filtered $\mathrm{Cu} \mathrm{K} \alpha(\lambda=0.15406 \mathrm{~nm})$ radiation. This instrument was operated at $30 \mathrm{kV}$ and $30 \mathrm{~mA}$ in a continuous scanning mode at a speed of $2^{\circ} \cdot \mathrm{min}^{-1}$ with a step width of $0.02^{\circ}$ from $10^{\circ}$ to $60^{\circ} 2 \theta$. Raman spectroscopy measurements were performed using an FT-Raman spectrometer (Bruker RAM II with a Ge detector) equipped with a $\mathrm{Nd}$ :YAG laser with the wavelength centered at $1064 \mathrm{~nm}$. UVvis diffuse reflectance spectra (DRS) were recorded from 200 to $800 \mathrm{~nm}$ using a UV-vis spectrophotometer (Shimadzu UV2600) equipped with an integrating sphere (ISR-2600 Plus) to determine the band gap of the materials. The measurements were performed in a total reflection mode using barium sulfate $\left(\mathrm{BaSO}_{4}\right)$ as the standard compound. The specific surface area (SSA) of the samples was calculated according to the BET model using the $\mathrm{N}_{2}$ adsorption data obtained at $-196{ }^{\circ} \mathrm{C}$ (Micrometrics ASAP 2000 instrument). All the samples were pretreated (degasified) via heating at $80{ }^{\circ} \mathrm{C}$ under vacuum until they reached a degassing pressure of less than $20 \mu \mathrm{mHg}$.

The morphology and size of the particles were investigated using field emission gun scanning electron microscopy (FESEM) (JEOL JSM 6701F). The semiquantitative atomic composition analysis and elemental mapping of $\mathrm{Bi}$ and $\mathrm{V}$ atoms were performed via energy-dispersive X-ray spectroscopy (EDX) using a Thermo Noran device coupled to a scanning electron microscope (JEOL JEM 2010). The formation of the heterostructures was confirmed via high resolution transmission electron microscopy (HRTEM) using a TECNAI G2 F20LaB6 instrument operated at $200 \mathrm{kV}$. The samples were prepared for TEM by wetting carbon-coated copper grids with a drop of the colloidal alcoholic suspensions and then drying the samples in air.

Evaluation of the Photocatalytic Performance and Photodegradation Mechanism. The photocatalytic activities of the as-synthesized samples were evaluated using the photodegradation of methylene blue (MB) dye. In a typical experiment, $10 \mathrm{mg}$ of the photocatalyst was added to $20 \mathrm{~mL}$ of a $5 \mathrm{mg} \cdot \mathrm{L}^{-1} \mathrm{MB}$ dye aqueous solution. The dispersions were stirred and exposed to visible irradiation using six lamps (Osram, $15 \mathrm{~W}$, maximum intensity at $440 \mathrm{~nm}$ ) in a homemade photoreactor maintained at $18{ }^{\circ} \mathrm{C}$. The photodegradation of $\mathrm{MB}$ was monitored at regular time intervals using UV-vis spectrophotometry (1601PC, Shimadzu) at an absorbance maximum of $665 \mathrm{~nm}$. Prior to irradiation, the suspensions were maintained in the dark for $12 \mathrm{~h}$ with magnetic stirring to guarantee the complete adsorption-desorption equilibrium. The adsorption capacity of the MB dye for the samples was negligible $(<5 \%)$ after $12 \mathrm{~h}$.

The lifetimes of the charge carriers of the as-synthesized samples were determined via time-resolved photoluminescence using time-correlated single photon counting (TCSPC). A 405 $\mathrm{nm}$ pulsed laser diode (LDH P-C-405, PicoQuant) with an approximate 50 ps pulse width and $40 \mathrm{MHz}$ repetition rate was used as the excitation source. The PL emission was spectrally 
resolved using collection optics and an emission monochromator. The TCSPC module (PicoHarp 300, PicoQuant) was used for ultrafast detection. The deconvolution of the PL decay was performed using fitting software (FluoFit, PicoQuant) to deduce the time constant associated with the exponential decay.

\section{RESULTS AND DISCUSSION}

$\mathrm{XRD}$ patterns of the as-synthesized samples (Figure 2) were obtained to confirm the presence of both the $\mathrm{BiVO}_{4}$ and $\mathrm{Bi}_{2} \mathrm{O}_{3}$
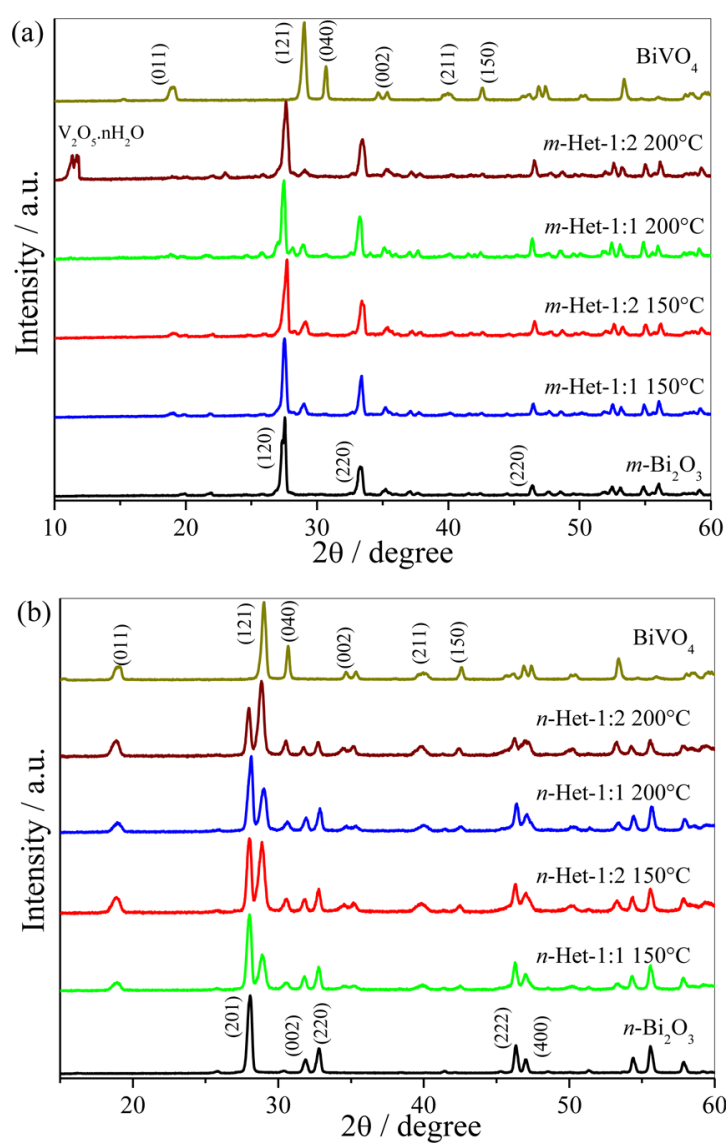

Figure 2. XRD patterns of (a) commercial $m-\mathrm{Bi}_{2} \mathrm{O}_{3}, \mathrm{BiVO}_{4}$, and the as-synthesized $\mathrm{Bi}_{2} \mathrm{O}_{3} / \mathrm{BiVO}_{4}$ heterostructures and of (b) commercial $n$ - $\mathrm{Bi}_{2} \mathrm{O}_{3}, \mathrm{BiVO}_{4}$, and the as-synthesized $\mathrm{Bi}_{2} \mathrm{O}_{3} / \mathrm{BiVO}_{4}$ heterostructures.

crystalline phases and to estimate the weight ratio between the phases. The hydrothermal treatment of $m-\mathrm{Bi}_{2} \mathrm{O}_{3}$ in the presence of the $\mathrm{V}$ precursor led to mixed crystalline phases that contained the monoclinic $\mathrm{Bi}_{2} \mathrm{O}_{3}$ (JCPDS, no. 41-1449) and monoclinic $\mathrm{BiVO}_{4}$ (JCPDS, no. 83-1699). The weight percentage of $\mathrm{BiVO}_{4}$ in each heterostructured sample was calculated using the relative intensities of the main peaks $(\%=$ $\left.I_{\mathrm{BiVO}_{4}(121)} /\left(I_{\mathrm{Bi}_{2} \mathrm{O}_{3}(120)}+I_{\mathrm{BiVO}_{4}(121)}\right)\right)^{41}$ identified in Figure 2a and Table 1. The increases in the concentration of the $\mathrm{V}$ precursor and the hydrothermal treatment temperature (except for the $m$-Het-1:2 $200{ }^{\circ} \mathrm{C}$ sample) resulted in larger amounts of monoclinic $\mathrm{BiVO}_{4}$ forming on the as-synthesized samples. The $m$-Het-1:2 $200{ }^{\circ} \mathrm{C}$ sample showed a different behavior and formed a spurious phase (probably $\mathrm{V}_{2} \mathrm{O}_{5} \cdot n \mathrm{H}_{2} \mathrm{O}$, as indicated by the peaks at $2 \theta \approx 11.4^{\circ}$ and $11.6^{\circ}$ ) due to the excess of unreacted $\mathrm{V}$ precursor and the suitable thermal energy for the crystallization of vanadium compounds. ${ }^{42,43}$
Table 1. Weight Percentage of the Monoclinic $\mathrm{BiVO}_{4}$ Phase in the As-Synthesized Samples (Error < 3\%)

\begin{tabular}{|c|c|c|}
\hline samples & wt $\% \mathrm{BiVO}_{4}{ }^{a}$ & wt $\% \mathrm{BiVO}_{4}{ }^{b}$ \\
\hline Het-1:1 $150{ }^{\circ} \mathrm{C}$ & 16 & 33 \\
\hline Het-1:2 $150{ }^{\circ} \mathrm{C}$ & 18 & 48 \\
\hline Het-1:1 $200{ }^{\circ} \mathrm{C}$ & 18 & 37 \\
\hline Het-1:2 $200{ }^{\circ} \mathrm{C}$ & 13 & 60 \\
\hline
\end{tabular}

${ }^{a}$ Percentage of the $\mathrm{BiVO}_{4}$ phase in the heterostructure formed from $m-\mathrm{Bi}_{2} \mathrm{O}_{3}{ }^{b}$ Percentage of the $\mathrm{BiVO}_{4}$ phase in the heterostructure formed from $n-\mathrm{Bi}_{2} \mathrm{O}_{3}$

The effect of the $\mathrm{Bi}_{2} \mathrm{O}_{3}$ precursor particle size on heterostructure synthesis was evaluated using the nanometric $\mathrm{Bi}_{2} \mathrm{O}_{3}$ (Figure $2 \mathrm{~b}$ ). As observed earlier, despite the difference in the precursor particle size, a mixed-crystalline phase containing the tetragonal $\mathrm{Bi}_{2} \mathrm{O}_{3}$ (JCPDS, no. 27-0050) and monoclinic $\mathrm{BiVO}_{4}$ (JCPDS, no. 83-1699) crystalline phases was obtained (Figure 2b). However, the use of the $n-\mathrm{Bi}_{2} \mathrm{O}_{3}$ precursor in heterostructure synthesis resulted in the formation of a larger amount of $\mathrm{BiVO}_{4}$ compared to synthesis using the $m-\mathrm{Bi}_{2} \mathrm{O}_{3}$ precursor (Figure 2b, Table 1). The increases in the $\mathrm{V}$ precursor concentration and hydrothermal treatment temperature caused a larger amount of $\mathrm{BiVO}_{4}$ to form on the heterostructure. Therefore, the growth of $\mathrm{BiVO}_{4}$ on the $\mathrm{Bi}_{2} \mathrm{O}_{3}$ surface was proposed to follow a classical solubilizationprecipitation reaction mechanism, as shown in eqs 1 and 2 .

$$
\begin{aligned}
& \mathrm{NH}_{4} \mathrm{VO}_{3(\text { aq })} \rightarrow \mathrm{NH}_{4}^{+}{ }_{(\text {aq })}+\mathrm{VO}_{3}^{-}{ }_{(\text {aq })} \\
& 2 \mathrm{Bi}_{2} \mathrm{O}_{3}+4 \mathrm{VO}_{3}^{-}{ }_{(\text {aq })}+4 \mathrm{H}^{+}{ }_{(\mathrm{aq})} \rightarrow 4 \mathrm{BiVO}_{4}+2 \mathrm{H}_{2} \mathrm{O}
\end{aligned}
$$

These results are in agreement with the findings of Liang et al., ${ }^{44}$ De-Kun et al., ${ }^{45}$ and $\mathrm{Yu}$ et al., ${ }^{46}$ who proposed synthesis routes driven by the solubility differences between $\mathrm{Bi}_{2} \mathrm{~S}_{3}$ and $\mathrm{Bi}_{2} \mathrm{O}_{2} \mathrm{CO}_{3}$, between $\mathrm{Bi}_{2} \mathrm{~S}_{3}$ and $\mathrm{BiVO}_{4}$, and between $\mathrm{CuS}$ and $\mathrm{ZnS}$, respectively. These studies used the principle that compounds with a high solubility can be converted into compounds with a low solubility, as observed by the formation of $\mathrm{Bi}_{2} \mathrm{~S}_{3}$ from $\mathrm{Bi}_{2} \mathrm{O}_{2} \mathrm{CO}_{3}$ and $\mathrm{BiVO}_{4}$ due to its lower solubility compared to the other compounds. ${ }^{4,45,47}$ The crystallite size from the XRD data and the particle size from the specific surface area were calculated for the $m-\mathrm{Bi}_{2} \mathrm{O}_{3}$ and $n-\mathrm{Bi}_{2} \mathrm{O}_{3}$ samples (Table $\mathrm{S} 1$ ). The comparison between crystallite and particle sizes revealed that both samples are polycrystalline; therefore, it is expected that the particle size may be more influential on the solubility than the crystallite size. Samples $m$ $\mathrm{Bi}_{2} \mathrm{O}_{3}$ and $n-\mathrm{Bi}_{2} \mathrm{O}_{3}$ exhibited approximately the same crystallite size, which confirms that the expected differences in solubility are not related to the single-crystal solubility. We correlated $\mathrm{Bi}_{2} \mathrm{O}_{3}$ solubility to the particle size using the OstwaldFreundlich equation

$$
S=S_{0} e^{\left(4 \gamma_{\mathrm{SL}} V_{\mathrm{M}} / R T d\right)}
$$

where $S_{0}$ is the solubility of the flat surface, $\gamma_{\mathrm{SL}}$ is the solidliquid interfacial energy, $V_{\mathrm{M}}$ is the molar volume of the solid phase, $R$ is the gas constant, $d$ is the particle diameter, and $T$ is the absolute temperature. The particle diameter $(d)$ of the $m$ $\mathrm{Bi}_{2} \mathrm{O}_{3}$ and $n-\mathrm{Bi}_{2} \mathrm{O}_{3}$ samples was the only parameter that changed. Therefore, the higher solubility of $n-\mathrm{Bi}_{2} \mathrm{O}_{3}$ compared to $m-\mathrm{Bi}_{2} \mathrm{O}_{3}$ is related to the smaller particle size and higher surface area. 

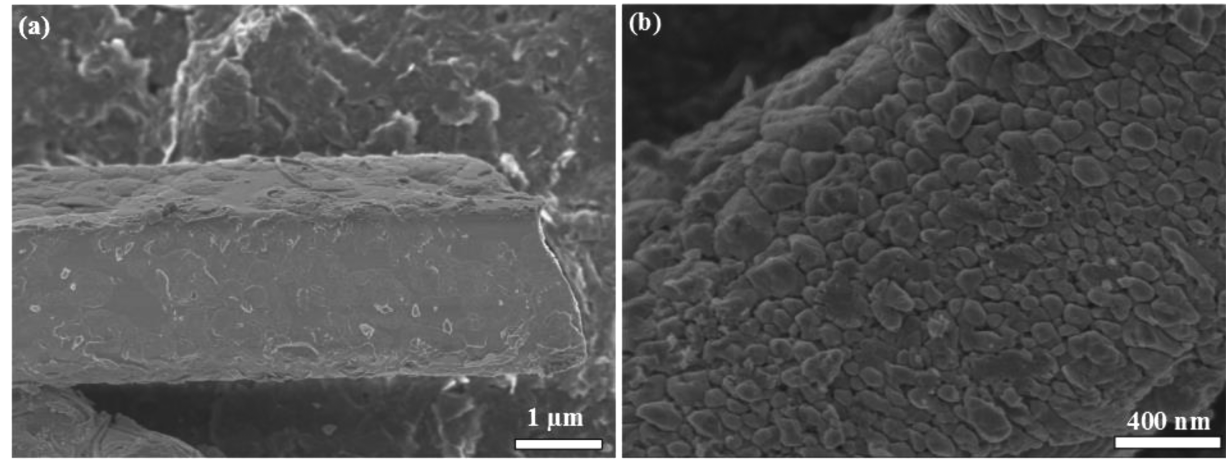

Figure 3. Representative FE-SEM images of (a) commercial $m-\mathrm{Bi}_{2} \mathrm{O}_{3}$ and (b) $m$-Het-1:1 $200{ }^{\circ} \mathrm{C}$.
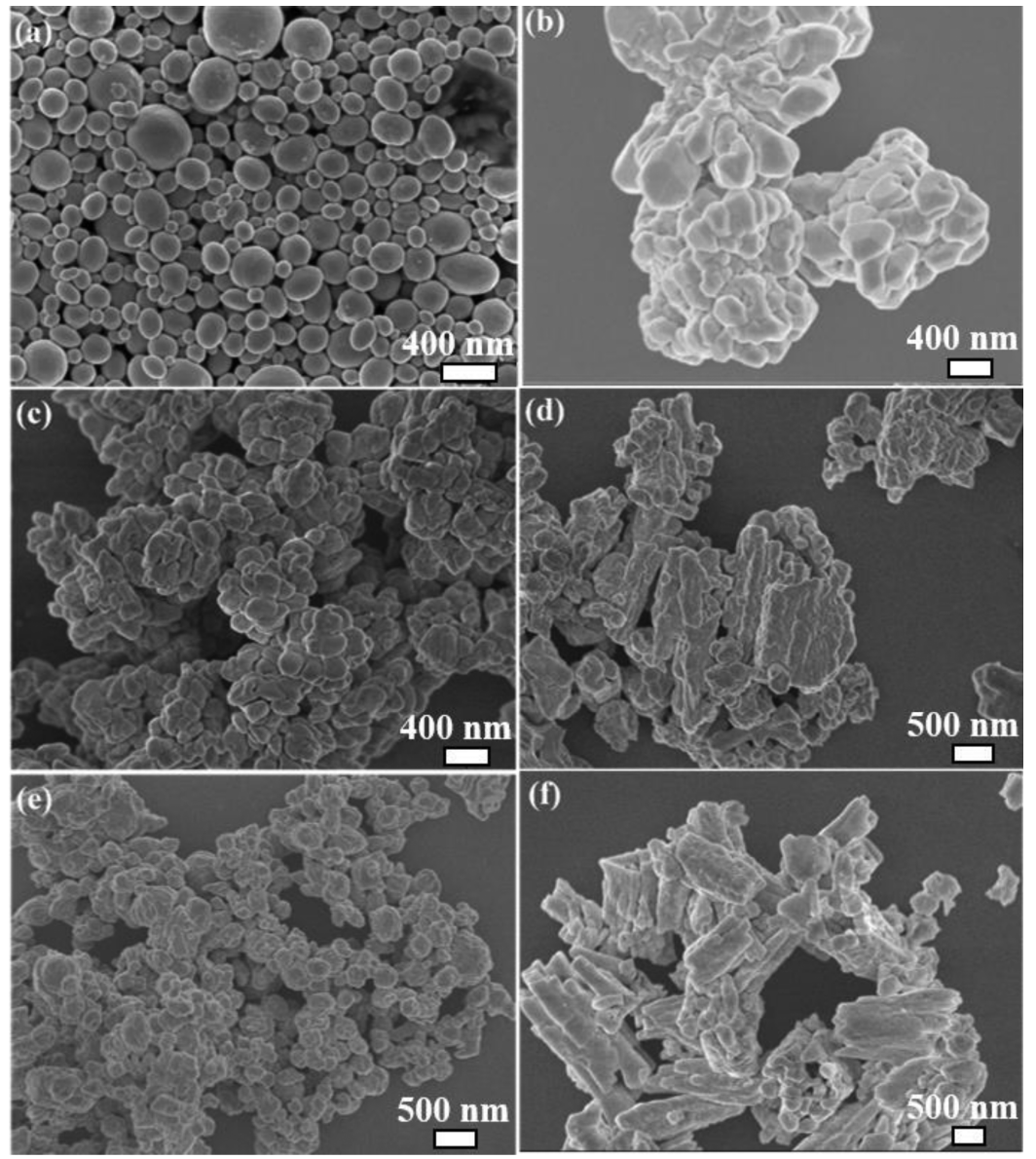

Figure 4. Representative FE-SEM images of (a) commercial $n$ - $\mathrm{Bi}_{2} \mathrm{O}_{3}$, (b) $\mathrm{BiVO}_{4}$, (c) $n$-Het-1:1 $150{ }^{\circ} \mathrm{C}$, (d) $n$-Het-1:2 $150{ }^{\circ} \mathrm{C}$, (e) $n$-Het-1:1 $200{ }^{\circ} \mathrm{C}$, and (f) $n$-Het-1:2 $200{ }^{\circ} \mathrm{C}$.

Considering that $\mathrm{NH}_{4} \mathrm{VO}_{3}$ is highly water-soluble, adsorption to $\mathrm{Bi}_{2} \mathrm{O}_{3}$ is expected to be the first step in the surface reaction that occurs via partial dissolution and fast reprecipitation prior to the subsequent growth. However, this reaction must occur locally to ensure heterostructure formation because precipitation can lead to a mixture of phases. Representative SEM images of the as-synthesized heterostructured samples were analyzed to determine the morphology and confirm the crystallization/growth of the $\mathrm{BiVO}_{4}$ nanoparticles on the $m$ and $n-\mathrm{Bi}_{2} \mathrm{O}_{3}$ surfaces (Figures 3 and 4 , respectively). The $m$ $\mathrm{Bi}_{2} \mathrm{O}_{3}$ surface showed the presence of rodlike, micrometric particles with smooth surfaces. In the case of the m-Het-1:1 200 ${ }^{\circ} \mathrm{C}$ sample, particles with a size and morphology similar to those of the $m-\mathrm{Bi}_{2} \mathrm{O}_{3}$ precursor were observed, indicating that $m-\mathrm{Bi}_{2} \mathrm{O}_{3}$ was not fully solubilized and reprecipitated under this condition. However, the existence of a rougher surface composed of a large number of quasi-spherical nanoparticles could be attributed to the $\mathrm{BiVO}_{4}$ phase. The EDX spectrum and elemental mapping image showed the presence of $\mathrm{Bi}$ and $\mathrm{V}$ in the $m$-Het-1:1 $200{ }^{\circ} \mathrm{C}$ sample (see the Supporting Information, Figure S1), as expected. Figure S1d shows that $\mathrm{V}$ was concentrated on the particle surface, confirming that the spherical nanoparticles were related to $\mathrm{BiVO}_{4}$ and grew evenly on the $m-\mathrm{Bi}_{2} \mathrm{O}_{3}$ surface. In the case of the $m$-Het-1:2 $200{ }^{\circ} \mathrm{C}$ sample, the EDX spectrum and elemental mapping image of the $\mathrm{Bi}$ and $\mathrm{V}$ atoms (Figure S2) confirmed the formation of regions 


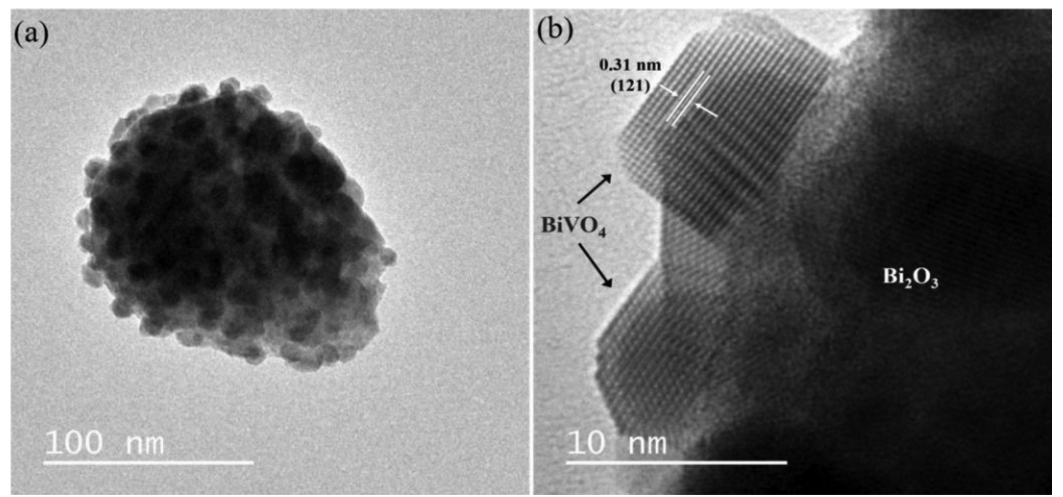

Figure 5. (a) TEM and (b) HRTEM images of the $n$-Het-1:1 $200{ }^{\circ} \mathrm{C}$ sample.

with only $\mathrm{V}$ atom, which could be attributed to the spurious $\mathrm{V}_{2} \mathrm{O}_{5} \cdot n \mathrm{H}_{2} \mathrm{O}$ crystalline phase identified by the XRD patterns. In addition, the growth of the phases was segregated, and the $\mathrm{Bi}$ and $\mathrm{V}$ atoms had different spatial positions, in agreement with the XRD observations.

The $n-\mathrm{Bi}_{2} \mathrm{O}_{3}$ sample exhibited a uniform, spherical morphology with an average particle size of $150 \mathrm{~nm}$ and a smooth surface, ${ }^{25}$ as shown in Figure 4a. The $n$-Het-1:1 $150{ }^{\circ} \mathrm{C}$ sample had particles with a size and morphology similar to those of $n-\mathrm{Bi}_{2} \mathrm{O}_{3}$ (Figure $4 \mathrm{c}$ ), which confirmed that this oxide was not fully solubilized during the hydrothermal treatment at $150{ }^{\circ} \mathrm{C}$. However, the surface of the $n$-Het-1:1 $150{ }^{\circ} \mathrm{C}$ sample was rough, with a large number of nanospheres, which could be due to the formation of $\mathrm{BiVO}_{4}$ on the $n-\mathrm{Bi}_{2} \mathrm{O}_{3}$ surface. The $n$ Het-1:2 $150{ }^{\circ} \mathrm{C}$ sample had particles with a different morphology and larger particle size compared to those of the $n-\mathrm{Bi}_{2} \mathrm{O}_{3}$ precursor. This finding could be explained by considering that, under this synthesis condition, excess $\mathrm{V}$ precursor resulted in some $n-\mathrm{Bi}_{2} \mathrm{O}_{3}$ particles being completely converted to $\mathrm{BiVO}_{4}$, and further growth led to phase segregation.

For the $n$-Het-1:1 $200{ }^{\circ} \mathrm{C}$ sample, the particle size and morphology were very similar to those of the $n-\mathrm{Bi}_{2} \mathrm{O}_{3}$ precursor, but the sample had a rough surface, indicating that $\mathrm{BiVO}_{4}$ grew on the $\mathrm{Bi}_{2} \mathrm{O}_{3}$ surface. This result was supported by the EDX spectrum and the elemental mapping image (Figure S3), which showed that, under this synthesis condition, the Bi and $\mathrm{V}$ atoms were homogeneously distributed in the particle and confirmed the growth of $\mathrm{BiVO}_{4}$ on the $\mathrm{Bi}_{2} \mathrm{O}_{3}$ surface. The n-Het-1:2 $200{ }^{\circ} \mathrm{C}$ sample presented a completely different morphology and particle size (Figure $4 \mathrm{f}$ ) compared to those of the $n-\mathrm{Bi}_{2} \mathrm{O}_{3}$ precursor (Figure $4 \mathrm{a}$ ), indicating that there was segregation of $\mathrm{BiVO}_{4}$ after its formation, in agreement with the growth mechanism proposed for the $n$-Het-1:2 $150{ }^{\circ} \mathrm{C}$ sample. This finding was confirmed by the EDX spectrum and the elemental mapping of the $\mathrm{Bi}$ and $\mathrm{V}$ atoms in the $n$-Het-1:2 150 ${ }^{\circ} \mathrm{C}$ heterostructured sample (Figure S4), where the $\mathrm{V}$ atoms were segregated in specific positions, suggesting that there were two different phases in the same particle. Therefore, excess V precursor during synthesis had a deleterious effect on the preparation of heterostructures via growth of $\mathrm{BiVO}_{4}$ on the $\mathrm{Bi}_{2} \mathrm{O}_{3}$ surface because there was a high degree of segregation between the crystalline phases under these conditions; this effect was more pronounced at higher hydrothermal treatment temperatures.

Formation of the $\mathrm{Bi}_{2} \mathrm{O}_{3} / \mathrm{BiVO}_{4}$ heterojunction was confirmed by the TEM and HRTEM images obtained for the $n$ -
Het-1:1 $200{ }^{\circ} \mathrm{C}$ sample (Figure 5). The TEM image revealed the presence of faceted nanoparticles with sizes smaller than 10 $\mathrm{nm}$ on the $\mathrm{Bi}_{2} \mathrm{O}_{3}$ surface. However, the HRTEM image of this sample (Figure $5 \mathrm{~b}$ ) showed that the nanoparticles of $\mathrm{BiVO}_{4}$ and $\mathrm{Bi}_{2} \mathrm{O}_{3}$ coexisted in the same region in the monoclinic and tetragonal phases, respectively. The growth of $\mathrm{BiVO}_{4}$ on the $\mathrm{Bi}_{2} \mathrm{O}_{3}$ surface was identified by its interlayer distance of 0.31 $\mathrm{nm}$ for the (121) plane. This result confirmed the formation of heterojunctions between $\mathrm{Bi}_{2} \mathrm{O}_{3}$ and $\mathrm{BiVO}_{4}$.

Raman spectroscopy analyses were performed to determine the medium-range structures of the as-synthesized heterostructured samples. The Raman scattering spectra of the $m-\mathrm{Bi}_{2} \mathrm{O}_{3}$ precursor and the corresponding heterostructures are shown in Figure 6a. The $m-\mathrm{Bi}_{2} \mathrm{O}_{3}$ precursor showed the typical Raman spectrum of monoclinic, crystalline $\mathrm{Bi}_{2} \mathrm{O}_{3}$ with characteristic
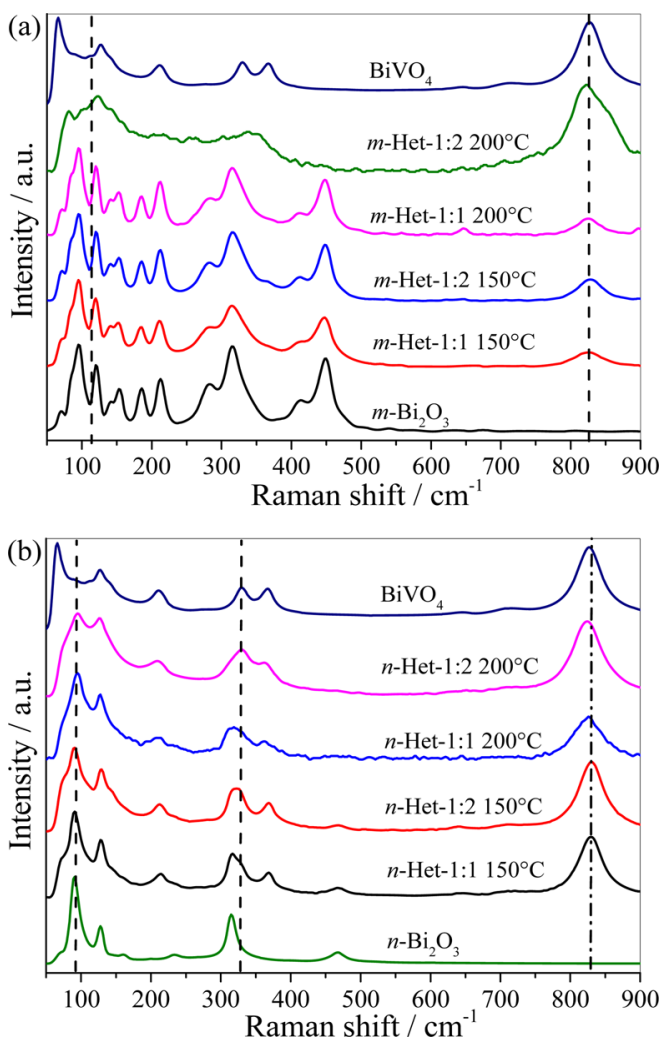

Figure 6. Raman scattering spectra of (a) $m-\mathrm{Bi}_{2} \mathrm{O}_{3}, \mathrm{BiVO}_{4}$, and the assynthesized $m-\mathrm{Bi}_{2} \mathrm{O}_{3} / \mathrm{BiVO}_{4}$ heterostructures and of (b) $n-\mathrm{Bi}_{2} \mathrm{O}_{3}$, $\mathrm{BiVO}_{4}$, and the as-synthesized $n-\mathrm{Bi}_{2} \mathrm{O}_{3} / \mathrm{BiVO}_{4}$ heterostructures. 
peaks at $70,95,122,141,153,186,213,315,413,450$, and 542 $\mathrm{cm}^{-1}$, and these vibrational modes had $A_{g}$ or $B_{g}$ symmetry (or both). ${ }^{48}$ The Raman scattering peaks observed in the region below $120 \mathrm{~cm}^{-1}$ were mainly assigned to shifts in the $\mathrm{Bi}$ atoms. The peaks in the range from 120 to $150 \mathrm{~cm}^{-1}$ were attributed to shifts in the $\mathrm{Bi}$ and $\mathrm{O}$ atoms, and those above $150 \mathrm{~cm}^{-1}$ were assigned to displacements of the $\mathrm{O}$ atoms. ${ }^{49}$ The $\mathrm{BiVO}_{4}$ sample showed a characteristic Raman spectrum with five main peaks at $120,200,330,362$, and $826 \mathrm{~cm}^{-1} .50$ The peaks at 120 and $200 \mathrm{~cm}^{-1}$ were assigned to the external vibrational mode of $\mathrm{BiVO}_{4}$, the peaks at 330 and $362 \mathrm{~cm}^{-1}$ were related to the asymmetric and symmetric deformation modes of the $\mathrm{V}-\mathrm{O}$ bonds on tetrahedral $\mathrm{VO}_{4}$, respectively, and the peak at 826 $\mathrm{cm}^{-1}$ was assigned to the symmetric stretching mode of the V$\mathrm{O}$ bonds with $A_{g}$ symmetry. ${ }^{51}$ The Raman spectra of the heterostructured $m-\mathrm{Bi}_{2} \mathrm{O}_{3} / \mathrm{BiVO}_{4}$ samples showed peaks related to both the crystalline phases $\left(\mathrm{Bi}_{2} \mathrm{O}_{3}\right.$ and $\left.\mathrm{BiVO}_{4}\right)$, which was in good agreement with the $\mathrm{XRD}$ analysis. There was a gradual increase in the intensity of the peaks related to the $\mathrm{BiVO}_{4}$ phase as the amount of the $\mathrm{V}$ precursor and the hydrothermal treatment temperature increased. The Raman spectrum of the $n-\mathrm{Bi}_{2} \mathrm{O}_{3}$ precursor showed six well-defined peaks at 70, 91, 127, 232,315 , and $467 \mathrm{~cm}^{-1}$, which were attributed to tetragonal, crystalline $\mathrm{Bi}_{2} \mathrm{O}_{3}$ (Figure $6 \mathrm{~b}$ ), and the peaks at 70 and $91 \mathrm{~cm}^{-1}$ were related to the $E_{g}$ and $A_{g}$ symmetry vibration modes of the $\mathrm{Bi}$ atoms, respectively. ${ }^{48-50}$ The peaks at 127,315 , and 467 $\mathrm{cm}^{-1}$ were assigned to $\mathrm{Bi}-\mathrm{O}$ bond stretching. ${ }^{48-50}$ In the case of the $n-\mathrm{Bi}_{2} \mathrm{O}_{3} / \mathrm{BiVO}_{4}$ heterostructured samples, the Raman spectra had peaks related to both of the crystalline phase constituents $\left(\mathrm{Bi}_{2} \mathrm{O}_{3}\right.$ and $\left.\mathrm{BiVO}_{4}\right)$, which was in good agreement with the XRD results.

Due to the fundamental role of the electronic properties of a semiconductor in heterogeneous photocatalysis applications, the band gap values of $m-\mathrm{Bi}_{2} \mathrm{O}_{3}, n-\mathrm{Bi}_{2} \mathrm{O}_{3}$, and their corresponding heterostructures were determined by applying the Tauc equation to the DRS data for the samples (Figure 7, Table 2). The $m-\mathrm{Bi}_{2} \mathrm{O}_{3}$ precursor had a band gap of $2.70 \mathrm{eV}$, which was in agreement with the values previously reported in the literature. ${ }^{52}$ The heterostructured $m-\mathrm{Bi}_{2} \mathrm{O}_{3} / \mathrm{BiVO}_{4}$ samples showed different band gap values with small fluctuations, and the values ranged from 2.35 to $2.40 \mathrm{eV}$. This result confirmed that $\mathrm{BiVO}_{4}$ evenly decorated the surface of the $m-\mathrm{Bi}_{2} \mathrm{O}_{3}$ precursor because the band gap values are characteristic of monoclinic $\mathrm{BiVO}_{4}$. The results demonstrated that the $\mathrm{Bi}: \mathrm{V}$ ratio and the hydrothermal treatment temperature did not affect the band gap characteristics. The band gap of the $n-\mathrm{Bi}_{2} \mathrm{O}_{3}$ precursor was $2.60 \mathrm{eV}$ (Table 2). ${ }^{52}$ Different band gap features were observed for the $n-\mathrm{Bi}_{2} \mathrm{O}_{3} / \mathrm{BiVO}_{4}$ samples (Figure $7 \mathrm{~b}$ ). The heterostructured $n-\mathrm{Bi}_{2} \mathrm{O}_{3} / \mathrm{BiVO}_{4}$ samples showed two band gaps related to $\mathrm{BiVO}_{4}$ and $n-\mathrm{Bi}_{2} \mathrm{O}_{3}$, with values of approximately 2.40 and $2.60 \mathrm{eV}$, respectively.

As expected, the specific surface areas of the as-synthesized samples (Table 3) decreased due to particle growth upon the formation of $\mathrm{BiVO}_{4}$ on the $\mathrm{Bi}_{2} \mathrm{O}_{3}$ surface, which was observed in the SEM and TEM images (Figures 3-5). This finding indicated that any positive effect on the photocatalytic performance of the heterostructures was not related to the specific surface area.

The photocatalytic properties of the $m-\mathrm{Bi}_{2} \mathrm{O}_{3} / \mathrm{BiVO}_{4}$ heterostructures were evaluated using the photodegradation of $\mathrm{MB}$ dye, and the results were compared to those obtained using the pure $m-\mathrm{Bi}_{2} \mathrm{O}_{3}$ sample (Figure $8 \mathrm{a}$ ). All the $m-\mathrm{Bi}_{2} \mathrm{O}_{3}$ / $\mathrm{BiVO}_{4}$ heterostructures were photoactive for $\mathrm{MB}$ dye photo-
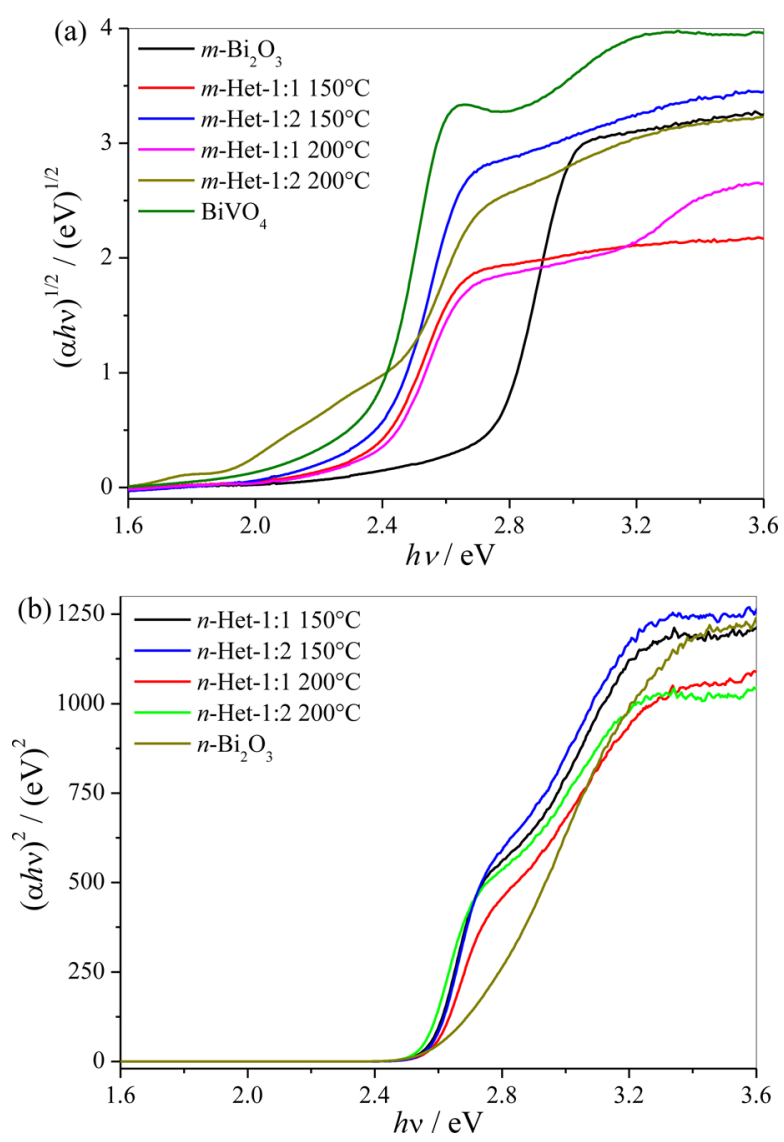

Figure 7. Band gap determination using indirect and direct Tauc plots with the DRS data for (a) $m-\mathrm{Bi}_{2} \mathrm{O}_{3}$, (b) $n-\mathrm{Bi}_{2} \mathrm{O}_{3}$, and the corresponding heterostructured samples.

Table 2. Band Gap Values of Pure $m-\mathrm{Bi}_{2} \mathrm{O}_{3}$ and $n-\mathrm{Bi}_{2} \mathrm{O}_{3}$ and Their Corresponding Heterostructures

\begin{tabular}{lcc}
\multicolumn{1}{c}{ samples } & band gap $(\mathrm{eV})^{a}$ & band gap $(\mathrm{eV})^{b}$ \\
$\mathrm{Bi}_{2} \mathrm{O}_{3}$ & $2.70 \pm 0.09$ & $2.60 \pm 0.01$ \\
$\mathrm{Het}-1: 1-150$ & $2.35 \pm 0.04$ & $2.50 \pm 0.03$ \\
$\mathrm{Het}-1: 2-150$ & $2.40 \pm 0.10$ & $2.40 \pm 0.01$ \\
$\mathrm{Het}-1: 1-200$ & $2.35 \pm 0.04$ & $2.50 \pm 0.02$ \\
Het-1:2-200 & $2.30 \pm 0.03$ & $2.40 \pm 0.02$
\end{tabular}

${ }^{a} \mathrm{Band}$ gap values of the heterostructures formed from $m-\mathrm{Bi}_{2} \mathrm{O}_{3}{ }^{b} \mathrm{Band}$ gap values of the heterostructures formed from $n-\mathrm{Bi}_{2} \mathrm{O}_{3}$

Table 3. Specific Surface Area Values (SSAs) of the $m-\mathrm{Bi}_{2} \mathrm{O}_{3}$ and $n-\mathrm{Bi}_{2} \mathrm{O}_{3}$ Precursors and Their Most Photoactive Heterostructures

\begin{tabular}{|c|c|}
\hline samples & SSA $\left(\mathrm{m}^{2} \cdot \mathrm{g}^{-1}\right)$ \\
\hline$m-\mathrm{Bi}_{2} \mathrm{O}_{3}$ & 0.15 \\
\hline$m$-Het-1:1 $200{ }^{\circ} \mathrm{C}$ & 0.10 \\
\hline$n-\mathrm{Bi}_{2} \mathrm{O}_{3}$ & 2.80 \\
\hline$n$-Het-1:1 $200{ }^{\circ} \mathrm{C}$ & 0.40 \\
\hline $\mathrm{BiVO}_{4}$ & 0.60 \\
\hline
\end{tabular}

degradation and showed higher activity than the $m-\mathrm{Bi}_{2} \mathrm{O}_{3}$ precursor and the blank experiment (both conditions exhibited negligible photoactivity). The blank experiment in our study was an aqueous solution of the $\mathrm{MB}$ dye without any photocatalyst. On the basis of the reaction rate constants, which were calculated using the pseudo-first-order equation 

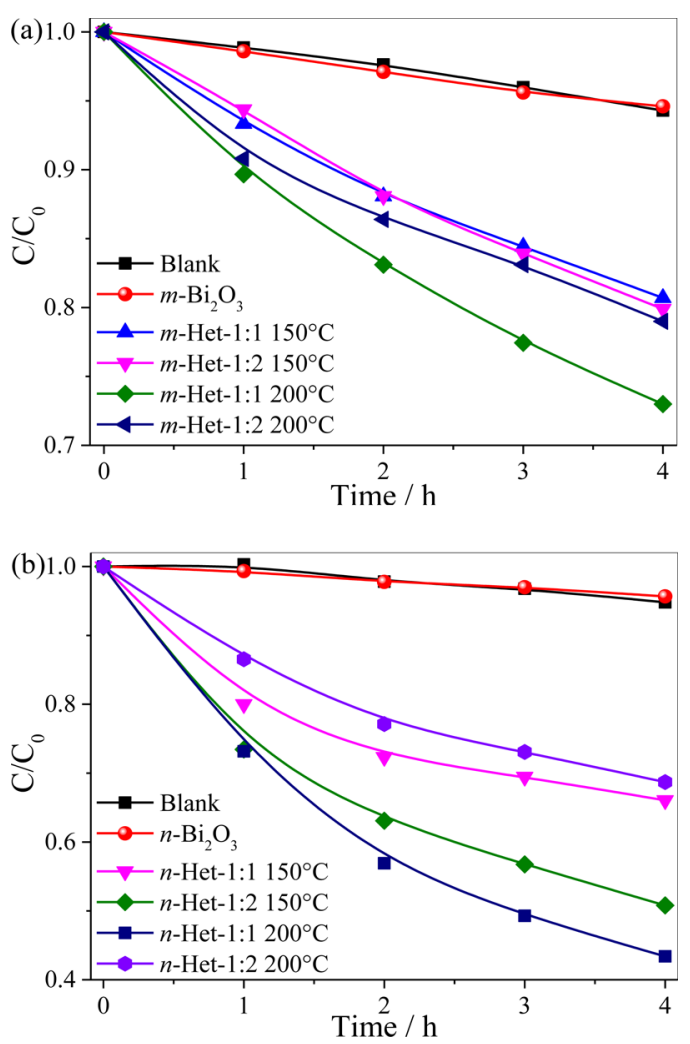

Figure 8. Kinetics curves for the $\mathrm{MB}$ dye $\left(5 \mathrm{mg} \cdot \mathrm{L}^{-1}\right)$ photodegradation catalyzed by (a) $m-\mathrm{Bi}_{2} \mathrm{O}_{3}$ and the $m-\mathrm{Bi}_{2} \mathrm{O}_{3} / \mathrm{BiVO}_{4}$ heterostructures and by (b) $n-\mathrm{Bi}_{2} \mathrm{O}_{3}$ and the $n-\mathrm{Bi}_{2} \mathrm{O}_{3} / \mathrm{BiVO}_{4}$ heterostructures.

(Table 4), the photoactivity followed the order: $m$-Het-1:1 200 ${ }^{\circ} \mathrm{C}>m$-Het-1:2 $200{ }^{\circ} \mathrm{C} \approx m$-Het-1:2 $150{ }^{\circ} \mathrm{C} \approx m$-Het-1:1 150

Table 4. First-Order Rate Constants $\left(k \times 10^{2}\right)$ for the MB Dye Photodegradation Reaction under Visible Irradiation Catalyzed by $\mathrm{Bi}_{2} \mathrm{O}_{3}$ and the Heterostructures

\begin{tabular}{lcc}
\multicolumn{1}{c}{ sample } & $\begin{array}{c}m-\mathrm{Bi}_{2} \mathrm{O}_{3} / \mathrm{BiVO}_{4} \\
k \times 10^{2}\left(\mathrm{~h}^{-1}\right)\end{array}$ & $\begin{array}{c}n-\mathrm{Bi}_{2} \mathrm{O}_{3} / \mathrm{BiVO}_{4} \\
k \times 10^{2}\left(\mathrm{~h}^{-1}\right)\end{array}$ \\
$\mathrm{Bi}_{2} \mathrm{O}_{3}$ & $1.3 \pm 0.2$ & $1.3 \pm 0.2$ \\
$\mathrm{Het}: 1150{ }^{\circ} \mathrm{C}$ & $5.0 \pm 0.3$ & $10.5 \pm 0.5$ \\
$\mathrm{Het}-1: 2150{ }^{\circ} \mathrm{C}$ & $5.4 \pm 0.3$ & $18.0 \pm 2.0$ \\
$\mathrm{Het}-1: 1200{ }^{\circ} \mathrm{C}$ & $7.1 \pm 0.7$ & $22.5 \pm 1.9$ \\
$\mathrm{Het}-1: 2200{ }^{\circ} \mathrm{C}$ & $5.3 \pm 0.4$ & $11.0 \pm 2.0$
\end{tabular}

${ }^{\circ} \mathrm{C}$. The heterostructure with the largest amount of $\mathrm{BiVO}_{4}$ showed the highest photoactivity for $\mathrm{MB}$ dye degradation, indicating that effective heterojunctions formed between the $m$ $\mathrm{Bi}_{2} \mathrm{O}_{3}$ and $\mathrm{BiVO}_{4}$ phases increased the charge carrier lifetime. Figure $8 \mathrm{~b}$ shows the $\mathrm{MB}$ dye photodegradation catalyzed by the $n-\mathrm{Bi}_{2} \mathrm{O}_{3} / \mathrm{BiVO}_{4}$ heterostructures. As previously observed for the $m$-Het heterostructures, all the heterostructures showed higher photoactivity than the precursor $\left(n-\mathrm{Bi}_{2} \mathrm{O}_{3}\right)$. On the basis of the reaction rate constants (Table 4 ), the photoactivity of the heterostructures was in the following order: $n$-Het-1:1200 ${ }^{\circ} \mathrm{C}>$ $n$-Het-1:2 $150{ }^{\circ} \mathrm{C}>n$-Het-1:1 $150{ }^{\circ} \mathrm{C} \approx n$-Het-1:2 $200{ }^{\circ} \mathrm{C}$. For these samples, an intermediate composition between the $n$ $\mathrm{Bi}_{2} \mathrm{O}_{3}$ and $\mathrm{BiVO}_{4}$ phases resulted in improved photoactivity. The higher activity of the $n$-Het-1:1200 ${ }^{\circ} \mathrm{C}$ sample was due to an ideal amount of $\mathrm{BiVO}_{4}(37 \mathrm{wt} \%)$ and better distribution of $\mathrm{BiVO}_{4}$ on the $\mathrm{Bi}_{2} \mathrm{O}_{3}$ surface because the heterostructures obtained using excess $\mathrm{V}$ precursor $\left(n-\mathrm{Het}-1: 2 \quad 150{ }^{\circ} \mathrm{C}\right.$ and $n$ Het-1:2 $200{ }^{\circ} \mathrm{C}$ ) had high amounts of $\mathrm{BiVO}_{4}$ and segregation between the phases, as observed in the SEM images and the EDX elemental mapping.

Despite the obvious formation of heterojunctions between the $\mathrm{Bi}_{2} \mathrm{O}_{3}$ and $\mathrm{BiVO}_{4}$ phases, an additional investigation comparing the heterostructures ( $m$-Het-1:1 $200{ }^{\circ} \mathrm{C}$ and $n$ Het-1:1 $\left.200{ }^{\circ} \mathrm{C}\right)$ with the two isolated phases $\left(\mathrm{Bi}_{2} \mathrm{O}_{3}\right.$ and $\left.\mathrm{BiVO}_{4}\right)$ and the corresponding physical mixtures was needed to confirm the effect of the heterojunctions and formation of the type-II heterostructure. The $m$-Het-1:1 $200{ }^{\circ} \mathrm{C}$ heterostructure exhibited lower activity for $\mathrm{MB}$ dye photodegradation compared to that of pure $\mathrm{BiVO}_{4}$ (Figure 9a). However, the
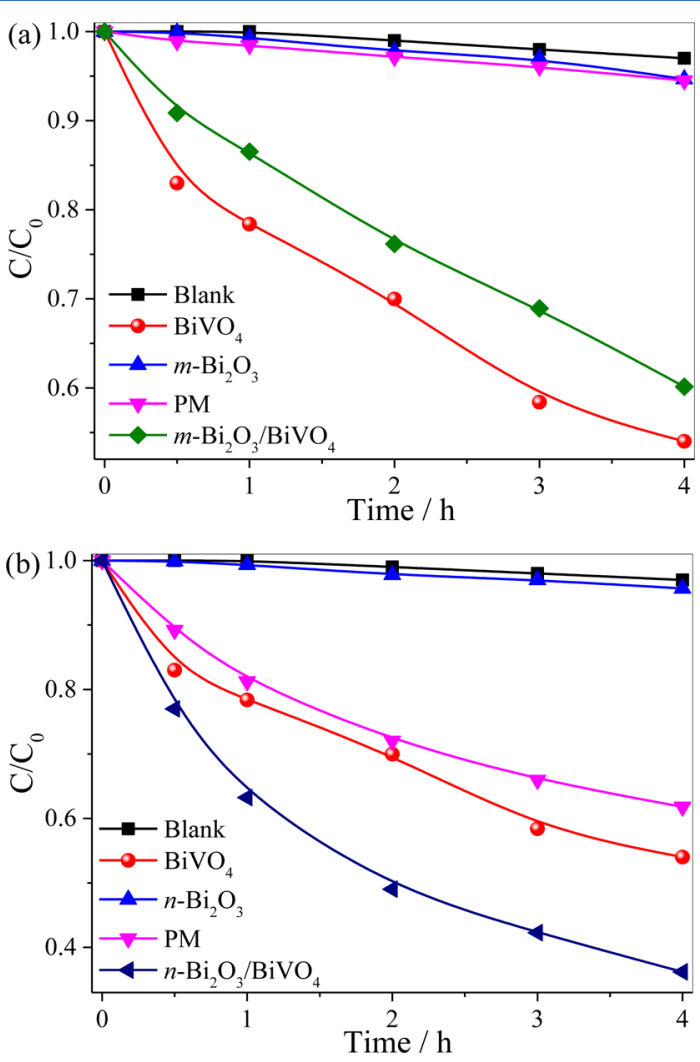

Figure 9. Photocatalytic performance in $\mathrm{MB}$ dye $\left(5 \mathrm{mg} \cdot \mathrm{L}^{-1}\right)$ degradation using the heterostructures obtained with the precursors (a) $m-\mathrm{Bi}_{2} \mathrm{O}_{3}$ and (b) $n-\mathrm{Bi}_{2} \mathrm{O}_{3}$ as well as their corresponding physical mixtures (PMs) and the isolated phases.

heterostructure showed higher photoactivity than the physical mixture of $\mathrm{BiVO}_{4}$ and $m-\mathrm{Bi}_{2} \mathrm{O}_{3}$ prepared in the same proportions as $m$-Het-1:1 $200{ }^{\circ} \mathrm{C}$. This heterostructured sample showed a lower activity than pure $\mathrm{BiVO}_{4}$ due to the large amount of the $m-\mathrm{Bi}_{2} \mathrm{O}_{3}$ precursor ( $82 \mathrm{wt} \%$ ), which exhibits insignificant photoactivity for $\mathrm{MB}$ dye photodegradation under visible irradiation. The $n$-Het-1:1 $200{ }^{\circ} \mathrm{C}$ sample showed superior photoactivity for $\mathrm{MB}$ dye degradation (Figure $9 \mathrm{~b})$ compared to the isolated phases $\left(n-\mathrm{Bi}_{2} \mathrm{O}_{3}\right.$ and $\left.\mathrm{BiVO}_{4}\right)$ and the corresponding physical mixture. Hence, the as-synthesized $m$-Het-1:1 $200{ }^{\circ} \mathrm{C}$ and $n$-Het-1:1 $200{ }^{\circ} \mathrm{C}$ samples both showed higher photocatalytic performances than their corresponding physical mixtures, indicating that the formation of the heterojunctions increased the charge carrier lifetimes probably due to type-II heterostructure formation. 
The results showed that the heterostructures obtained using the $n-\mathrm{Bi}_{2} \mathrm{O}_{3}$ precursor were more efficient than the heterostructures obtained using the $m-\mathrm{Bi}_{2} \mathrm{O}_{3}$ precursor. The $n-\mathrm{Bi}_{2} \mathrm{O}_{3} /$ $\mathrm{BiVO}_{4}$ heterostructures provided an $\mathrm{MB}$ dye degradation rate approximately 2-fold higher than that obtained using the $m$ $\mathrm{Bi}_{2} \mathrm{O}_{3} / \mathrm{BiVO}_{4}$ heterostructures. This result was expected based on the previous analysis because the heterostructures that were synthesized using the nanometric $\mathrm{Bi}_{2} \mathrm{O}_{3}$ particles possessed a larger amount of $\mathrm{BiVO}_{4}$ on their surfaces than the heterostructures synthesized using the micrometric $\mathrm{Bi}_{2} \mathrm{O}_{3}$ particles. This difference resulted in the increased formation of heterojunctions between the $\mathrm{Bi}_{2} \mathrm{O}_{3}$ and $\mathrm{BiVO}_{4}$ phases. These effects on photocatalytic performance can be clearly seen from the pseudo-first-order reaction rate constants for $\mathrm{MB}$ photodegradation as a function of the amount of the $\mathrm{BiVO}_{4}$ phase in the heterostructures (Figure 10).

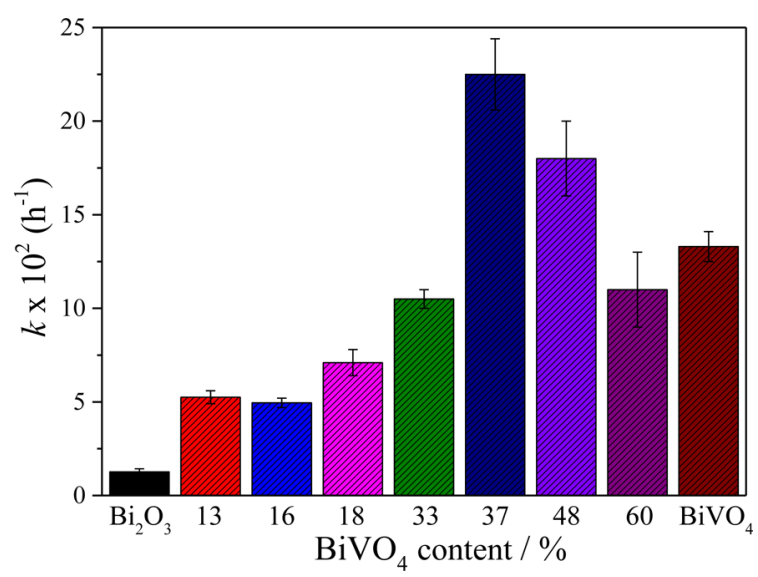

Figure 10. Pseudo-first-order rate constants for the $\mathrm{MB}$ dye photodegradation reaction as a function of the $\mathrm{BiVO}_{4}$ content in the heterostructures.

Finally, to confirm the formation of the $n-\mathrm{Bi}_{2} \mathrm{O}_{3} / \mathrm{BiVO}_{4}$ heterostructure, the electron/hole pair lifetime was calculated using time-resolved photoluminescence (TRPL). The photoluminescence decay spectra at $545 \mathrm{~nm}$ for the $\mathrm{BiVO}_{4}$ and $n$ $\mathrm{Bi}_{2} \mathrm{O}_{3} / \mathrm{BiVO}_{4}$ samples are shown in Figure 11. The TRPL

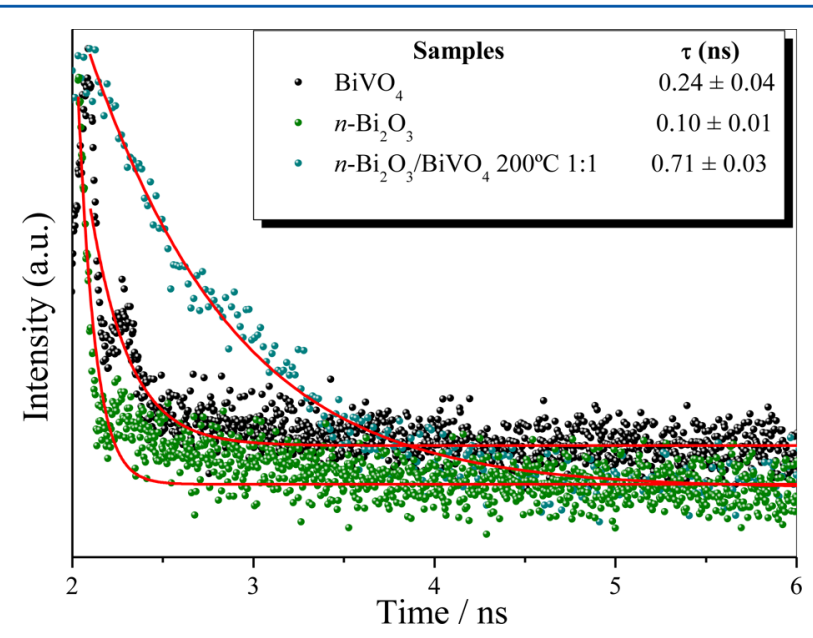

Figure 11. Observed (points) and calculated (lines) time-resolved photoluminescence intensities (decay lifetimes) for the $n-\mathrm{Bi}_{2} \mathrm{O}_{3} /$ $\mathrm{BiVO}_{4}, \mathrm{BiVO}_{4}$, and $n-\mathrm{Bi}_{2} \mathrm{O}_{3}$ samples. The powders were excited at 405 $\mathrm{nm}$, and photoluminescence was monitored at $545 \mathrm{~nm}$. decays for both samples were fitted using a first-order exponential function to calculate the charge carrier lifetime. The electron/hole pair lifetime of the $n-\mathrm{Bi}_{2} \mathrm{O}_{3} / \mathrm{BiVO}_{4}$ heterostructure (Het-1:1 $200{ }^{\circ} \mathrm{C}$ ) was significantly higher than that of the pure $\mathrm{BiVO}_{4}$ and $\mathrm{Bi}_{2} \mathrm{O}_{3}$. The lifetime of the band-band emission (the electron/hole pair recombination at $545 \mathrm{~nm}$ ) of the $n-\mathrm{Bi}_{2} \mathrm{O}_{3} / \mathrm{BiVO}_{4}$ heterostructure was $0.71 \mathrm{~ns}$, while the lifetimes for $\mathrm{BiVO}_{4}$ and $\mathrm{Bi}_{2} \mathrm{O}_{3}$ were approximately 0.24 and $0.10 \mathrm{~ns}$, respectively. These results showed that the lifetime of the electron/hole pair in the $n-\mathrm{Bi}_{2} \mathrm{O}_{3} / \mathrm{BiVO}_{4}$ heterostructure was 2.9-fold and 7.1-fold longer than that in pure $\mathrm{BiVO}_{4}$ and $\mathrm{Bi}_{2} \mathrm{O}_{3}$, respectively, proving that the junction of $\mathrm{Bi}_{2} \mathrm{O}_{3}$ with $\mathrm{BiVO}_{4}$ formed a suitable type-II heterostructure.

The conduction band (CB) and valence band (VB) potentials of $\mathrm{BiVO}_{4}$ are 0.3 and $2.7 \mathrm{eV}$, respectively. ${ }^{38,53}$ The $\mathrm{CB}$ and $\mathrm{VB}$ potentials of tetragonal $\mathrm{Bi}_{2} \mathrm{O}_{3}$ are 2.9 and $0.6 \mathrm{eV}$, respectively. ${ }^{53,54} \mathrm{BiVO}_{4}$ is an intrinsic n-type semiconductor, while $\mathrm{Bi}_{2} \mathrm{O}_{3}$ is as an intrinsic p-type semiconductor. ${ }^{26,55}$ Thus, before the semiconductors come into contact, the conduction and valence band edges of the p-type $\mathrm{Bi}_{2} \mathrm{O}_{3}$ are lower than those of the n-type $\mathrm{BiVO}_{4}$, and the Fermi level of the $\mathrm{Bi}_{2} \mathrm{O}_{3}$ is lower than that of the $\mathrm{BiVO}_{4}$ (Figure S5). After the semiconductors come into contact, the Fermi level of $\mathrm{Bi}_{2} \mathrm{O}_{3}$ moves up, while the Fermi level of $\mathrm{BiVO}_{4}$ moves down until the Fermi levels of $\mathrm{Bi}_{2} \mathrm{O}_{3}$ and $\mathrm{BiVO}_{4}$ become the same. ${ }^{37,32,33} \mathrm{~A}$ type-II heterojunction ( $\mathrm{p}-\mathrm{n}$ junction) is formed, and electron transfer occurs from $\mathrm{Bi}_{2} \mathrm{O}_{3}$ to $\mathrm{BiVO}_{4}$ until their Fermi levels align; i.e., the semiconductor system reaches a thermal equilibrium state. As a result, the whole energy band of $\mathrm{Bi}_{2} \mathrm{O}_{3}$ increases while that of $\mathrm{BiVO}_{4}$ decreases. In the end, $\mathrm{Bi}_{2} \mathrm{O}_{3}$ has a conduction band and valence band higher than $\mathrm{BiVO}_{4}$. Therefore, the interface between the phases allows transfer of the photogenerated electrons from the p-type $\left(\mathrm{Bi}_{2} \mathrm{O}_{3}\right)$ to the $n$ type $\left(\mathrm{BiVO}_{4}\right)$ semiconductor. The photogenerated holes are transferred from the n-type $\left(\mathrm{BiVO}_{4}\right)$ to the p-type $\left(\mathrm{Bi}_{2} \mathrm{O}_{3}\right)$ semiconductor because the valence band level of $\mathrm{BiVO}_{4}$ is lower than that of $\mathrm{Bi}_{2} \mathrm{O}_{3}{ }^{32-34}$ Hence, the photogenerated electrons accumulate in the $\mathrm{BiVO}_{4}$ conduction band, while the photogenerated holes accumulate in the $\mathrm{Bi}_{2} \mathrm{O}_{3}$ valence band, which is where the $\mathrm{MB}$ dye oxidation reaction occurs. The enhanced photocatalytic activity of the $\mathrm{Bi}_{2} \mathrm{O}_{3} / \mathrm{BiVO}_{4}$ heterostructures can be explained by the spatial separation of the photogenerated electron/hole pair.

\section{CONCLUSIONS}

An alternative method based on solubility differences was developed using preformed micro- or nanometric particles of $\mathrm{Bi}_{2} \mathrm{O}_{3}$ to obtain $\mathrm{Bi}_{2} \mathrm{O}_{3} / \mathrm{BiVO}_{4}$ heterostructures. The technique enabled efficient heterojunction tailoring, and the amount of $\mathrm{BiVO}_{4}$ in the heterostructure was dependent on the particle size of the preformed $\mathrm{Bi}_{2} \mathrm{O}_{3}$ due to the solubility differences between the micro- and nanometric $\mathrm{Bi}_{2} \mathrm{O}_{3}$. The growth mechanism of $\mathrm{BiVO}_{4}$ on the self-sacrificial $\mathrm{Bi}_{2} \mathrm{O}_{3}$ surface was elucidated, and the formation of the $\mathrm{Bi}_{2} \mathrm{O}_{3} / \mathrm{BiVO}_{4}$ heterojunctions was confirmed using HRTEM images. The photocatalytic activity was enhanced compared to the isolated phases due to the formation of the $\mathrm{Bi}_{2} \mathrm{O}_{3} / \mathrm{BiVO}_{4}$ heterostructures. The formation of the type-II heterostructure increased the spatial separation of the photogenerated electron/hole pair, which increased its lifetime, as demonstrated by the PL and TRPL analyses. 


\section{ASSOCIATED CONTENT}

\section{S Supporting Information}

The Supporting Information is available free of charge on the ACS Publications website at DOI: 10.1021/acs.jpcc.7b03340.

SEM images, EDX spectra, and elemental mapping (PDF)

\section{AUTHOR INFORMATION}

\section{Corresponding Author}

*E-mail: osmando_iq@hotmail.com.

ORCID $\odot$

Osmando F. Lopes: 0000-0003-2077-4583

Caue Ribeiro: 0000-0003-4279-2053

\section{Present Address}

"Instituto de Química de São Carlos, Universidade de São Paulo - USP, Av. Trabalhador São Carlense, 400, CEP 13566590, São Carlos-SP, Brazil.

\section{Author Contributions}

The manuscript was written through contributions of all authors. All authors have given approval to the final version of the manuscript.

Notes

The authors declare no competing financial interest.

\section{ACKNOWLEDGMENTS}

The authors are grateful to the Ministry of Science, Technology, and Innovation (through SisNANO Program National System of Laboratories in Nanotechnology), the National Council for Scientific and Technological Development (CNPq, grant \# 402.287/2013-4), Coordination for the Improvement of Higher Education Personnel (CAPES), Sao Paulo Research Foundation (FAPESP grants \# 13/13888-0, \# 13/17639-4, and \# 15/12304-0), for financial support. We are also grateful to the Laboratory for Research in Energy and Materials - Brazilian Nanotechnology National Laboratory (LNNano) for technical support during the X-ray photoelectron spectroscopy work (grant \# XPS-18304). We are grateful to Dr. Débora Milori (Embrapa Instrumentação) for help with the TRPL facilities.

\section{REFERENCES}

(1) de Castro, I. A.; Avansi, W.; Ribeiro, C. $\mathrm{WO}_{3} / \mathrm{TiO}_{2}$ Heterostructures Tailored by the Oriented Attachment Mechanism: Insights from Their Photocatalytic Properties. CrystEngComm 2014, $16,1514$.

(2) de Castro, I. A.; de Oliveira, J. A.; Paris, E. C.; Giraldi, T. R.; Ribeiro, C. Production of Heterostructured $\mathrm{TiO}_{2} / \mathrm{WO}_{3}$ Nanoparticulated Photocatalysts through a Simple One Pot Method. Ceram. Int. 2015, 41, 3502-3510.

(3) de Mendonça, V. R.; Lopes, O. F.; Fregonesi, R. P.; Giraldi, T. R.; Ribeiro, C. $\mathrm{TiO}_{2}-\mathrm{SnO}_{2}$ Heterostructures Applied to Dye Photodegradation: The Relationship between Variables of Synthesis and Photocatalytic Performance. Appl. Surf. Sci. 2014, 298, 182-191.

(4) Mourão, H. A. J. L.; Avansi, W., Jr.; Ribeiro, C. Hydrothermal Synthesis of Ti Oxide Nanostructures and $\mathrm{TiO}_{2}: \mathrm{SnO}_{2}$ Heterostructures Applied to the Photodegradation of Rhodamine B. Mater. Chem. Phys. 2012, 135, 524-532.

(5) Wang, L.; Wei, H.; Fan, Y.; Gu, X.; Zhan, J. One-Dimensional $\mathrm{CdS} / \alpha-\mathrm{Fe}_{2} \mathrm{O}_{3}$ and $\mathrm{CdS} / \mathrm{Fe}{ }_{3} \mathrm{O}_{4}$ Heterostructures: Epitaxial and Nonepitaxial Growth and Photocatalytic Activity. J. Phys. Chem. C 2009, 113, 14119-14125.

(6) Lin, X.; Xing, J.; Wang, W.; Shan, Z.; Xu, F.; Huang, F. Photocatalytic Activities of Heterojunction Semiconductors $\mathrm{Bi}_{2} \mathrm{O}_{3}$ /
$\mathrm{BaTiO}_{3}$ : A Strategy for the Design of Efficient Combined Photocatalysts. J. Phys. Chem. C 2007, 111, 18288-18293.

(7) Liu, Y.; Gu, Y.; Yan, X.; Kang, Z.; Lu, S.; Sun, Y.; Zhang, Y. Design of Sandwich-Structured $\mathrm{ZnO} / \mathrm{ZnS} / \mathrm{Au}$ Photoanode for Enhanced Efficiency of Photoelectrochemical Water Splitting. Nano Res. 2015, 8, 2891-2900.

(8) Wu, M.; Chen, W.; Shen, Y.; Huang, F.; Li, C.; Li, S. In Situ Growth of Matchlike $\mathrm{ZnO} / \mathrm{Au}$ Plasmonic Heterostructure for Enhanced Photoelectrochemical Water Splitting. ACS Appl. Mater. Interfaces 2014, 6, 15052-15060.

(9) Malara, F.; Minguzzi, A.; Marelli, M.; Morandi, S.; Psaro, R.; Dal Santo, V.; Naldoni, A. $\alpha-\mathrm{Fe}_{2} \mathrm{O}_{3} / \mathrm{NiOOH}$ : An Effective Heterostructure for Photoelectrochemical Water Oxidation. ACS Catal. 2015, 5, 52925300.

(10) Li, X.; Liu, H.; Luo, D.; Li, J.; Huang, Y.; Li, H.; Fang, Y.; Xu, Y.; $\mathrm{Zhu}, \mathrm{L}$. Adsorption of $\mathrm{CO}_{2}$ on Heterostructure $\mathrm{CdS}\left(\mathrm{Bi}_{2} \mathrm{~S}_{3}\right) / \mathrm{TiO}_{2}$ Nanotube Photocatalysts and Their Photocatalytic Activities in the Reduction of $\mathrm{CO}_{2}$ to Methanol under Visible Light Irradiation. Chem. Eng. J. 2012, 180, 151-158.

(11) Ehsan, M. F.; He, T. In Situ Synthesis of ZnO/ZnTe Common Cation Heterostructure and Its Visible-Light Photocatalytic Reduction of $\mathrm{CO}_{2}$ into CH4. Appl. Catal., B 2015, 166-167, 345-352.

(12) Tan, L. L.; Ong, W. J.; Chai, S. P.; Goh, B. T.; Mohamed, A. R. Visible-Light-Active Oxygen-Rich $\mathrm{TiO}_{2}$ Decorated 2D Graphene Oxide with Enhanced Photocatalytic Activity toward Carbon Dioxide Reduction. Appl. Catal., B 2015, 179, 160-170.

(13) Wang, J.; Ji, G.; Liu, Y.; Gondal, M. A.; Chang, X. $\mathrm{Cu}_{2} \mathrm{O} / \mathrm{TiO}_{2}$ Heterostructure Nanotube Arrays Prepared by an Electrodeposition Method Exhibiting Enhanced Photocatalytic Activity for $\mathrm{CO}_{2}$ Reduction to Methanol. Catal. Commun. 2014, 46, 17-21.

(14) Ge, M.; Li, Y.; Liu, L.; Zhou, Z.; Chen, W. $\mathrm{Bi}_{2} \mathrm{O}_{3}-\mathrm{Bi}_{2} \mathrm{WO}_{6}$ Composite Microspheres: Hydrothermal Synthesis and Photocatalytic Performances. J. Phys. Chem. C 2011, 115, 5220-5225.

(15) Ahmed, M. G.; Kandiel, T. A.; Ahmed, A. Y.; Kretschmer, I.; Rashwan, F.; Bahnemann, D. Enhanced Photoelectrochemical Water Oxidation on Nanostructured Hematite Photoanodes via $\mathrm{P}_{-} \mathrm{CaFe}_{2} \mathrm{O}_{4} /$ n- $\mathrm{Fe}_{2} \mathrm{O}_{3}$ Heterojunction Formation. J. Phys. Chem. C 2015, 119, $5864-5871$

(16) He, Z.; Shi, Y.; Gao, C.; Wen, L.; Chen, J.; Song, S. BiOCl/ $\mathrm{BiVO}_{4}$ P-N Heterojunction with Enhanced Photocatalytic Activity under Visible-Light Irradiation. J. Phys. Chem. C 2014, 118, 389-398.

(17) de Mendonça, V. R.; Dalmaschio, C. J.; Leite, E. R.; Niederberger, M.; Ribeiro, C. Heterostructure Formation from Hydrothermal Annealing of Preformed Nanocrystals. J. Mater. Chem. A 2015, 3, 2216-2225.

(18) Zheng, Y.; Zheng, L.; Zhan, Y.; Lin, X.; Zheng, Q.; Wei, K. Ag/ $\mathrm{ZnO}$ Heterostructure Nanocrystals: Synthesis, Characterization, and Photocatalysis. Inorg. Chem. 2007, 46, 6980-6986.

(19) Tian, J.; Zhao, Z.; Kumar, A.; Boughton, R. I.; Liu, H. Recent Progress in Design, Synthesis, and Applications of One-Dimensional $\mathrm{TiO}_{2}$ Nanostructured Surface Heterostructures: A Review. Chem. Soc. Rev. 2014, 43, 6920-6937.

(20) Lin, D.; Wu, H.; Zhang, R.; Pan, W. Enhanced Photocatalysis of Electrospun $\mathrm{Ag}-\mathrm{ZnO}$ Heterostructured Nanofibers. Chem. Mater. 2009, 21, 3479-3484.

(21) Amirav, L.; Alivisatos, a. P. Photocatalytic Hydrogen Production with Tunable Nanorod Heterostructures. J. Phys. Chem. Lett. 2010, 1, $1051-1054$

(22) Zheng, Y.; Chen, C.; Zhan, Y.; Lin, X.; Zheng, Q.; Wei, K.; Zhu, J. Photocatalytic Activity of $\mathrm{Ag} / \mathrm{ZnO}$ Heterostructure Nanocatalyst: Correlation between Structure and Property. J. Phys. Chem. C 2008, 112, 10773-10777.

(23) Liu, G.; Wang, L.; Yang, H. G.; Cheng, H.-M.; Lu, G. Q. TitaniaBased Photocatalysts-Crystal Growth, Doping and Heterostructuring. J. Mater. Chem. 2010, 20, 831-843.

(24) Maiti, S.; Debnath, T.; Ghosh, H. N. Elucidating the Electronic Cross Talk Dynamics Across the Hetero-Interface of Janus CdSe/PbSe Nanocrystals. J. Phys. Chem. C 2016, 120, 29054-29061. 
(25) Lopes, O. F.; Carvalho, K. T. G.; Macedo, G. K.; de Mendonça, V. R.; Avansi, W.; Ribeiro, C. Synthesis of $\mathrm{BiVO}_{4}$ via Oxidant PeroxoMethod: Insights into the Photocatalytic Performance and Degradation Mechanism of Pollutants. New J. Chem. 2015, 39, 6231-6237.

(26) Park, Y.; McDonald, K. J.; Choi, K.-S. Progress in Bismuth Vanadate Photoanodes for Use in Solar Water Oxidation. Chem. Soc. Rev. 2013, 42, 2321-2337.

(27) Zhang, L.; Wang, W.; Yang, J.; Chen, Z.; Zhang, W.; Zhou, L.; Liu, S. Sonochemical Synthesis of Nanocrystallite $\mathrm{Bi}_{2} \mathrm{O}_{3}$ as a VisibleLight-Driven Photocatalyst. Appl. Catal., A 2006, 308, 105-110.

(28) Hu, R.; Xiao, X.; Tu, S.; Zuo, X.; Nan, J. Synthesis of Flower-like Heterostructured $\beta-\mathrm{Bi}_{2} \mathrm{O}_{3} / \mathrm{Bi}_{2} \mathrm{O}_{2} \mathrm{CO}_{3}$ Microspheres Using $\mathrm{Bi}_{2} \mathrm{O}_{2} \mathrm{CO}_{3}$ Self-Sacrifice Precursor and Its Visible-Light-Induced Photocatalytic Degradation of O-Phenylphenol. Appl. Catal., B 2015, 163, 510-519.

(29) Wang, H.; Zhang, L.; Chen, Z.; Hu, J.; Li, S.; Wang, Z.; Liu, J.; Wang, X. Semiconductor Heterojunction Photocatalysts: Design, Construction, and Photocatalytic Performances. Chem. Soc. Rev. 2014, 43, 5234-5244.

(30) Flanagan, J. C.; Shim, M. Enhanced Air Stability, Charge Separation, and Photocurrent in $\mathrm{CdSe} / \mathrm{CdTe}$ Heterojunction Nanorods by Thiols. J. Phys. Chem. C 2015, 119, 20162-20168.

(31) Sun, S.; Wang, W.; Li, D.; Zhang, L.; Jiang, D. Solar Light Driven Pure Water Splitting on Quantum Sized $\mathrm{BiVO}_{4}$ without Any Cocatalyst. ACS Catal. 2014, 4, 3498-3503.

(32) Cheng, Y.; Wang, H.; Zhu, Y.; Liao, F.; Li, Z.; Li, J. One-Step Hydrothermal Synthesis of $\mathrm{BiVO}_{4}-\mathrm{Bi}_{2} \mathrm{O}_{3} \mathrm{P}-\mathrm{n}$ Heterojunction Composites and Their Enhanced Photocatalysis Properties. J. Mater. Sci.: Mater. Electron. 2015, 26, 1268-1274.

(33) Chen, L.; Zhang, Q.; Huang, R.; Yin, S.-F.; Luo, S.-L.; Au, C.-T. Porous Peanut-like $\mathrm{Bi}_{2} \mathrm{O}_{3}-\mathrm{BiVO}_{4}$ Composites with Heterojunctions: One-Step Synthesis and Their Photocatalytic Properties. Dalton Trans. 2012, 41, 9513-9518.

(34) Ye, K.-H.; Yu, X.; Qiu, Z.; Zhu, Y.; Lu, X.; Zhang, Y. Facile Synthesis of Bismuth Oxide/bismuth Vanadate Heterostructures for Efficient Photoelectrochemical Cells. RSC Adv. 2015, 5, 34152-34156. (35) Sun, J.; Li, X.; Zhao, Q.; Ke, J.; Zhang, D. Novel $\mathrm{V}_{2} \mathrm{O}_{5} / \mathrm{BiVO}_{4} /$ $\mathrm{TiO}_{2}$ Nanocomposites with High Visible-Light-Induced Photocatalytic Activity for the Degradation of Toluene. J. Phys. Chem. C 2014, 118, 10113-10121.

(36) Tsai, C. Y.; Liu, C. W.; Fan, C.; Hsi, H. C.; Chang, T.-Y. Synthesis of a $\mathrm{SnO}_{2} / \mathrm{TNT}$ Heterojunction Nanocomposite as a HighPerformance Photocatalyst. J. Phys. Chem. C 2017, 121, 6050-6059.

(37) Guan, M. L.; Ma, D. K.; Hu, S. W.; Chen, Y. J.; Huang, S. M. From Hollow Olive-Shaped $\mathrm{BiVO}_{4}$ to $\mathrm{N}-\mathrm{p}$ Core-Shell $\mathrm{BiVO}_{4} @ \mathrm{Bi}_{2} \mathrm{O}_{3}$ Microspheres: Controlled Synthesis and Enhanced Visible-LightResponsive Photocatalytic Properties. Inorg. Chem. 2011, 50, 800-805.

(38) Wu, Y.; Wang, J.; Huang, Y.; Wei, Y.; Sun, Z.; Zheng, X.; Zhang, C.; Zhou, N.; Fan, L.; Wu, J. Solvothermal Synthesis of $\mathrm{Bi}_{2} \mathrm{O}_{3} / \mathrm{BiVO}_{4}$ Heterojunction with Enhanced Visible-Light Photocatalytic Performances. J. Semicond. 2016, 37, 083004.

(39) Li, L.; Yan, B. $\mathrm{BiVO}_{4} / \mathrm{Bi}_{2} \mathrm{O}_{3}$ Submicrometer Sphere Composite: Microstructure and Photocatalytic Activity under Visible-Light Irradiation. J. Alloys Compd. 2009, 476, 624-628.

(40) Zhang, F.; Li, X.; Zhao, Q.; Chen, A. Facile and Controllable Modification of 3D $\operatorname{In}_{2} \mathrm{O}_{3}$ Microflowers with $\operatorname{In}_{2} \mathrm{~S}_{3}$ Nanoflakes for Efficient Photocatalytic Degradation of Gaseous Ortho -Dichlorobenzene. J. Phys. Chem. C 2016, 120, 19113-19123.

(41) Xue, Y.; Wang, X. The Effects of Ag Doping on Crystalline Structure and Photocatalytic Properties of $\mathrm{BiVO}_{4}$. Int. J. Hydrogen Energy 2015, 40, 5878-5888.

(42) Avansi, W., Jr.; Ribeiro, C.; Leite, E. R.; Mastelaro, V. R. Vanadium Pentoxide Nanostructures: An Effective Control of Morphology and Crystal Structure in Hydrothermal Conditions. Cryst. Growth Des. 2009, 9, 3626-3631.

(43) Avansi, W.; de Mendonça, V. R.; Lopes, O. F.; Ribeiro, C. Vanadium Pentoxide 1-D Nanostructures Applied to Dye Removal from Aqueous Systems by Coupling Adsorption and Visible-Light Photodegradation. RSC Adv. 2015, 5, 12000.
(44) Liang, N.; Zai, J.; Xu, M.; Zhu, Q.; Wei, X.; Qian, X. Novel $\mathrm{Bi}_{2} \mathrm{~S}_{3} / \mathrm{Bi}_{2} \mathrm{O}_{2} \mathrm{CO}_{3}$ Heterojunction Photocatalysts with Enhanced Visible Light Responsive Activity and Wastewater Treatment. J. Mater. Chem. A 2014, 2, 4208-4216.

(45) Ma, D.-K.; Guan, M.-L.; Liu, S.-S.; Zhang, Y.-Q.; Zhang, C.-W.; He, Y.-X.; Huang, S.-M. Controlled Synthesis of Olive-Shaped $\mathrm{Bi}_{2} \mathrm{~S}_{3}$ / $\mathrm{BiVO}_{4}$ Microspheres through a Limited Chemical Conversion Route and Enhanced Visible-Light-Responding Photocatalytic Activity. Dalton Trans. 2012, 41, 5581-5586.

(46) Yu, J.; Zhang, J.; Liu, S. Ion-Exchange Synthesis and Enhanced Visible-Light Photoactivity of $\mathrm{CuS} / \mathrm{ZnS}$ Nanocomposite Hollow Spheres. J. Phys. Chem. C 2010, 114, 13642-13649.

(47) Beberwyck, B. J.; Surendranath, Y.; Alivisatos, A. P. Cation Exchange: A Versatile Tool for Nanomaterials Synthesis. J. Phys. Chem. C 2013, 117, 19759-19770.

(48) Denisov, V. N.; Ivlev, A. N.; Lipin, A. S.; Mavrin, B. N.; Orlov, V. G. Raman Spectra and Lattice Dynamics of Single-Crystal Alpha$\mathrm{Bi}_{2} \mathrm{O}_{3}$. J. Phys.: Condens. Matter 1997, 9, 4967-4978.

(49) Ho, C.-H.; Chan, C.-H.; Huang, Y.-S.; Tien, L.-C.; Chao, L.-C. The Study of Optical Band Edge Property of Bismuth Oxide Nanowires $\alpha-\mathrm{Bi}_{2} \mathrm{O}_{3}$. Opt. Express 2013, 21, 9658-9659.

(50) Guo, Y.; Yang, X.; Ma, F.; Li, K.; Xu, L.; Yuan, X.; Guo, Y. Additive-Free Controllable Fabrication of Bismuth Vanadates and Their Photocatalytic Activity toward Dye Degradation. Appl. Surf. Sci. 2010, 256, 2215-2222.

(51) Obregón, S.; Colón, G. On the Different Photocatalytic Performance of $\mathrm{BiVO}_{4}$ Catalysts for Methylene Blue and Rhodamine B Degradation. J. Mol. Catal. A: Chem. 2013, 376, 40-47.

(52) Cheng, H.; Huang, B.; Lu, J.; Wang, Z.; Xu, B.; Qin, X.; Zhang, X.; Dai, Y. Synergistic Effect of Crystal and Electronic Structures on the Visible-Light-Driven Photocatalytic Performances of $\mathrm{Bi}_{2} \mathrm{O}_{3}$ Polymorphs. Phys. Chem. Chem. Phys. 2010, 12, 15468-15475.

(53) Xu, Y.; Schoonen, M. A. A. The Absolute Energy Positions of Conduction and Valence Bands of Selected Semiconducting Minerals. Am. Mineral. 2000, 85, 543-556.

(54) Huang, Y.; Wang, W.; Zhang, Q.; Cao, J.; Huang, R.; Ho, W.; Lee, S. C. In Situ Fabrication of $\alpha-\mathrm{Bi}_{2} \mathrm{O}_{3} / \mathrm{BiO}_{2} \mathrm{CO}_{3}$ Nanoplate Heterojunctions with Tunable Optical Property and Photocatalytic Activity. Sci. Rep. 2016, 6, 23435-23444.

(55) Zhu, G.; Liu, Y.; Hojamberdiev, M.; Han, J.; Rodríguez, J.; Bilmes, S. A.; Liu, P. Thermodecomposition Synthesis of Porous $\beta$ $\mathrm{Bi}_{2} \mathrm{O}_{3} / \mathrm{Bi}_{2} \mathrm{O}_{2} \mathrm{CO}_{3}$ Heterostructured Photocatalysts with Improved Visible Light Photocatalytic Activity. New J. Chem. 2015, 39, 95579568. 